\section{Pharmaceutical patent term extension and patent prosecution in Brazil (1997-2018)}

\author{
Extensão do prazo de vigência e tramitação de \\ patentes farmacêuticas no Brasil (1997-2018) \\ Extensión de la vigencia y tramitación de \\ patentes farmacéuticas en Brasil (1997-2018)
}

Eduardo Mercadante 1

Julia Paranhos 2

\begin{abstract}
In Brazil, if patent prosecution takes more than 10 years, this extra period is added to the regular 20-year term. This paper analyses all pharmaceutical patents granted by the Brazilian National Institute of Industrial Property (INPI) with term extension and later discusses some intellectual property and health policy implications. On average, pharmaceutical patent applications wait seven years after substantive examination is requested before being examined, which takes only three and a half years. Furthermore, the role of the Brazilian Health Regulatory Agency (Anvisa) in providing prior consent has a marginal effect in prolonging the prosecution. Therefore, the extension of pharmaceutical patents' term is caused by the number of pending applications per examiner, which halts the prosecution for double the time it takes to examine the applications. Thus, proper solutions should focus on reducing the backlog per examiner at the INPI, which has caused the extension of 92\% of the pharmaceutical patents in three and a half years, on average. We concluded that the Brazilian pharmaceutical patenting policy is biased towards the patentee. This imbalance will only be effectively corrected when the INPI is financially and administratively autonomous to reduce the ratio between the pharmaceutical patent application backlog and the number of examiners.
\end{abstract}

Drug Patents; Patent; Patent Indicators

\author{
Correspondence \\ E. Mercadante \\ Department of International Development, London School of \\ Economics and Political Sciences. \\ 64 Aldwych, London / London - WC2B 4DS, U.K. \\ edu.mercadante@gmail.com \\ 1 Department of International Development, London School of \\ Economics and Political Sciences, London, U.K. \\ 2 Instituto de Economia, Universidade Federal do Rio de Janeiro, \\ Rio de Janeiro, Brasil.
}




\section{Introduction}

Signed in 1994, the Trade-Related Aspects of Intellectual Property Rights (TRIPS) Agreement changed the intellectual property paradigm. Essentially, the three major changes imposed by TRIPS on every World Trade Organization (WTO) member were: (a) the prohibition to exclude any technological field from patenting; (b) the obligation to reform national legislations to guarantee the mandatory minimum requirements - although preserving some flexibilities -; and (c) the deadline for the harmonization process, depending on the income level ${ }^{1}$. This was especially to the detriment of developing countries, most of which enjoyed their discretionary powers under previous agreements, for example, excluding pharmaceuticals from patenting. We argue that developing countries' patent systems had less policy capacity and resources to implement the new rules, especially with the lack of qualified and experienced examiners in the patent offices 2,3,4,5. Even though some implemented TRIPS' minimum obligations, others chose to create even stronger intellectual property protection mechanisms. This study investigates how the Brazilian harmonization to TRIPS affected the patent office concerning pharmaceutical patent prosecution.

Brazil is a relevant case study of pharmaceutical patenting under TRIPS because the country had excluded this industry from patenting before TRIPS and chose to go even further in the harmonization process with the Industrial Property Law (LPI, Act n. 9,279 6), including TRIPS-plus dispositions 2,3,5,7. Enacted in 1996, the LPI anticipated the introduction of pharmaceutical patenting in Brazil to 1997, even though TRIPS allowed the country to wait until 2005. Another important element of the LPI that far exceeds the obligations of TRIPS was the pipeline mechanism, which allowed the applicant that had already obtained a patent in any other country to file another application in Brazil and it would be granted without substantive examination if it had not been introduced to any market and there was no effort to develop that specific invention in Brazil. This mechanism requires the abdication of substantive examination since these inventions were already in the public domain and would fail novelty screening.

In this study, the most important controversial element of the LPI is the minimum term of the patent. The LPI states, in Art. 40, that every invention patent has a term of 20 years from the filing date, as was established by TRIPS. Moreover, the Sole Paragraph of Art. 40 guarantees 10 years of protection after the grant date. If the Brazilian Patent Office, or the Brazilian National Institute of Industrial Property (INPI), takes more than 10 years to grant a patent, it will have protection for more than 20 years, without a limit. This form of automatic and unrestricted patent extension due to delayed prosecution was in no sense demanded by TRIPS and is found in no other country.

There is another element that makes pharmaceutical patent prosecution a special matter in the Brazilian experience of harmonization to TRIPS. Since pharmaceutical products had been excluded from patenting since 1945, and products since 1969, the INPI lacked the necessary personnel - in quantity, qualification, and experience - to examine the high influx of pharmaceutical applications because the office had never had to examine them since its creation in 1970 2. An effort to prevent the lack of capacity and experience from delaying examination was the inclusion in the LPI in 2001 of the prior consent (Art. 229-C), in accordance with the Doha Declaration on the TRIPS Agreement and Public Health. It requires pharmaceutical product and process patents to be sent to the Brazilian Health Regulatory Agency (Anvisa) for prior consent 5,7,8. However, this led to both agencies examining the same applications, which has been the target of much debate, even though studies show that disagreements in their decisions were much lower than expected 8. In 2017, the INPI and Anvisa published the Joint Ordinance no 1, limiting prior consent to health risk assessment and eventual subsidies regarding patentability criteria to be presented to the INPI examiner, which should be considered in the final decision.

This study considers the theoretical goal of patenting as the establishment of a contract between the patentee and society, in which the former receives exclusivity in the commercial exploitation in exchange for public and sufficient disclosure of knowledge 9,10. Thus, a double stimulus to innovation by the research and development (R\&D) expenditures is expected, introducing the invention and diffusing knowledge, which should induce the emergence of more innovations. Moreover, there should be a balance in these private and collective stimuli to prevent de facto disincentives to private investments and to mitigate the anticompetitive effects that restrict social welfare. Furthermore, this study 
builds upon literature on pharmaceutical innovation, identifying seven reasons for the prominence of patents: (a) it costs considerably less to copy than to innovate; (b) knowledge is reasonably easier than other technological fields to codify; (c) technologies have a longer life cycle; (d) demand is mainly price-inelastic; (e) R\&D is very costly; (f) the R\&D pipeline has a high attrition rate; and (g) broad, long-lasting patents create bigger artificial barriers to entry and market shares 11,12,13,14.

This study uses quantitative methods to investigate the term extension of Brazilian pharmaceutical patents by delayed prosecution as a consequence of the Brazilian intellectual property reform that reintroduced pharmaceutical patenting. Therefore, this research does not address the outcomes in the Brazilian pharmaceutical market. The aim is to see if the patenting system created with the TRIPS harmonization process promotes balanced stimuli to innovation.

Besides this Introduction and the Conclusion, this paper has four sections. In the Methodology section, the research methods are explained, and some important intellectual property definitions are made. Then, a snapshot of the INPI is presented to compare the office with nine others from developing and developed countries. Later, the results of the patent prosecution analysis are presented. Finally, we discuss the results, foreseeing policy implications, and recommendations.

\section{Methodology}

The ex-post statistical analysis of the term extension of pharmaceutical patents granted by the INPI, after Brazil became harmonized with the TRIPS Agreement, was done in two stages. First, the INPI was placed in an international perspective for a better understanding of the office as a whole. The comparison includes data extracted from the 2017 annual reports from nine other patent offices, regarding all applications since pharmaceutical-only data was impossible to find for all offices. For the higher standard, the selected offices were the five biggest, also called IP5: China (China National Intellectual Property - CNIPA), United States (United States Patent and Trademark Office - USPTO), Japan (Japan Patent Office - JPO), South Korea (Korean Intellectual Property Office - KIPO), and the European Patent Office (EPO). Furthermore, to include offices from countries closer to Brazil's socioeconomic development stage, the other four offices were: the other two BRICS countries that had available data, Russia (Russian Federal Service for Intellectual Property - ROSPATENT) and India (Intellectual Property Office/Controller General of Patents, Designs \& Trade Marks IPO/CGPDTM); and another country from Latin America, Mexico (Mexican Institute of Industrial Property - IMPI).

In the second stage, the prosecution process of pharmaceutical applications by the INPI was investigated to understand how each procedure contributes to the examination lag. The data was obtained through a Special Tabulation extracted on May 14th, 2018, by the Economic Affairs Advisory of the INPI (Aecon/INPI) from their Intellectual Property Statistics Database (Badepi), in its fifth version. The sample was restricted to the pharmaceutical invention patents that had already been granted by the INPI with term extension. Since few studies analyze patent prosecution in Brazil - Sampat \& Shalen 8 are the best work so far - this study plays a conservative role to only investigate granted patents, building a methodological basis for future studies on the prosecution of all patent applications. The sample was also restricted to the patents that can be extended, thus excluding pipeline and mailbox patents. The latter are those filed from the signature of TRIPS and before the LPI was promulgated.

The technology-IPC correspondence table established by the World Intellectual Property Organisation (WIPO), which uses the International Patent Classification (IPC) created in 1975, was used to define pharmaceutical patents. WIPO 15 proposes that pharmaceutical patents are preparations for medical, dental, or toilet purposes (A61K), excluding cosmetics or similar toilet preparations (A61K 8/00). Furthermore, preparations for dentistry (A61K 6/00) were also removed from this study, bringing the definition even closer to pharmaceutical drugs. Under this technology-IPC definition, the Special Tabulation provided by Aecon/INPI had 1,048 granted pharmaceutical patents. After removing 134 pipelines and 231 mailbox patents, there were 683 extendable patents, $630(92.2 \%)$ of which were actually granted with term extension. 
The analysis requires prior knowledge of the prosecution process at the INPI. From the deposit date, the application is kept secret for 18 months and then published in the Industrial Property Bulletin (RPI). Within 36 months of the deposit date, the applicant must request substantive examination, which will not start before 60 days from the publication. The applicant may also request fast tracking if the application is eligible for any of the INPI's programs, expediting the prosecution. If the application falls under Art. 229-C of the LPI, it will be sent to Anvisa for prior consent. In the end, the INPI examiner issues an opinion to grant or reject. The application may also be withdrawn or considered abandoned if the patentee fails to comply with technical or formal requirements or stops paying the annual fees 16 .

\section{The INPI in international comparison}

The INPI, created in 1970, is an interesting patent office to study from a policy perspective. Even though its creation Act n. 5,648 17 and the LPI guarantee the office's financial and administrative autonomy, it cannot independently hire examiners. Moreover, all revenues are diverted to other branches of government, meaning that its endowment is tied to the government's budgetary decision, which also restricts the capacity to invest in infrastructure. These restrictions in governance cannot be ignored when assessing how the INPI prosecutes patent applications.

In a general perspective, the international comparison of the INPI with nine other offices, from developing and developed countries, is presented in Table 1. The first relevant information is the number of patents filed, with Brazil placing as eighth, only ahead of Mexico. In terms of grants, Brazil is only behind the IP5, with almost one-tenth of the Chinese total. However, the other developing

Table 1

Comparison of the Brazilian National Institute of Industrial Property (INPI) with other patent offices, 2017.

\begin{tabular}{|c|c|c|c|c|c|c|c|c|c|}
\hline \multirow[t]{2}{*}{ Statistic } & \multicolumn{2}{|c|}{ Latin America } & \multicolumn{2}{|c|}{ BRICS } & \multicolumn{5}{|c|}{ IP5 } \\
\hline & Mexico & Brazil & Russia & India * & China & United States & Japan & Korea & EPO ** \\
\hline \multicolumn{10}{|l|}{ Deposits } \\
\hline Total (n) & 17,184 & 28,667 & 47,097 & 45,444 & $1,381,594$ & 606,956 & 318,479 & 204,775 & 165,590 \\
\hline Residents (\%) & 7.8 & 29.3 & 69.9 & 29.1 & 90.2 & 48.4 & 81.7 & 77.7 & 47.3 \\
\hline \multicolumn{10}{|l|}{ Grants } \\
\hline Total (n) & 8,510 & 6,250 & 43,028 & 9,847 & 420,144 & 318,829 & 199,577 & 120,662 & 105,635 \\
\hline Residents (\%) & 4.8 & 23.7 & 68.4 & 13.4 & 77.8 & 47.3 & 78.6 & 75.3 & 48.0 \\
\hline Population (million) & 129 & 209 & 144 & 1,339 & 1,386 & 326 & 127 & 51 & 619 \\
\hline $\begin{array}{l}\text { Residents' deposits per million } \\
\text { population }(n)\end{array}$ & 10 & 40 & 228 & 10 & 899 & 902 & 2,053 & 3,090 & 126 \\
\hline Backlog (thousand) & 56 & 225 & 24 & 204 & 1,432 & 546 & 172 & 151 & 407 \\
\hline Examiners $(\mathrm{n}) * \star \star$ & 128 & 206 & - & 434 & 11,421 & 8,147 & 1,696 & 866 & 4,378 \\
\hline Backlog per examiner (n) & 441 & 1,093 & - & 470 & 125 & 67 & 101 & 175 & 93 \\
\hline Period until final decision (years) \# & 3.5 & 10.2 & 0.8 & - & 1.8 & 2.2 & 1.2 & 1.3 & 2.1 \\
\hline
\end{tabular}

EPO: European Patent Office; IP5: Intellectual Property 5 offices.

Source: prepared by the authors, based on offices' annual reports.

Note: some data could not be found for every country.

* Data from India is from the fiscal year of 2016-2017;

** The EPO's population was defined as the sum of the 38 member countries. This data is just for comparison, given that the EPO has an autonomous budget, not receiving endowments from the countries periodically;

*** Considering only patent examiners that had passed the training stage;

\# There are methodological differences from when offices estimate their periods until the final decision: Brazil, United States and Russian from deposit Japan and Korea, from substantive examination request; China, from the beginning of the substantive examination; and the EPO, from the assignment of an examiner. The Mexican report only informed this period, without explaining how it was estimated. 
countries are more efficient than Brazil in prosecuting. In fact, it had the biggest backlog per examiner and, by far, the slowest prosecution among countries with available data.

The ratio of backlog per examiner is far worse than any other country not necessarily due to the volume of pending applications but because of the low number of examiners. The INPI had a backlog per examiner of 1,093 applications in 2017, composed of 225,115 pending applications and 206 examiners. For a high-standard comparison, the average for the IP5 was 112 applications per examiner, based on 541,669 pending applications and 5,302 examiners - with considerable variance among the offices. The Brazilian backlog was half the average of the IP5, and the number of examiners was more than 25-times smaller. Therefore, the data presents a scenario for the INPI where the office itself is inefficient in prosecuting patent applications, due to the very low number of examiners. However, this study investigates if this unbalance is caused by the examiners or an administrative failure due to few examiners for the size of the backlog.

\section{Results}

This section presents the analysis of the pharmaceutical patents granted with term extension in Brazil between 1997 and 2018: 630 or $92.2 \%$ of the extendable patents. It is divided into two parts. First, a general characterization of the patents based on the country of the first applicant, the dates of deposit and grant, Anvisa's prior consent, and fast track requests. Finally, some calculations of periods between relevant stages of prosecution.

\section{General characterization}

One relevant characteristic of the patents is the country of the first applicant. The Special Tabulation created by the INPI only has this information, and not the current owner, or the patentee at the moment of grant. The first applicant is enough for this study because it represents who invested in the invention that met the patenting criteria. As shown in Figure 1, there is a strong concentration: applicants from the United States filed $28.7 \%$ and the next top four countries filed $38.8 \%$, leaving $32.5 \%$ for the other 31 countries. It is noteworthy that Brazilians filed only $8.6 \%$ (54) of the granted pharmaceutical patents.

\section{Figure 1}

Top five countries of the first applicant of pharmaceutical patents at the Brazilian National Institute of Industrial Property (INPI).

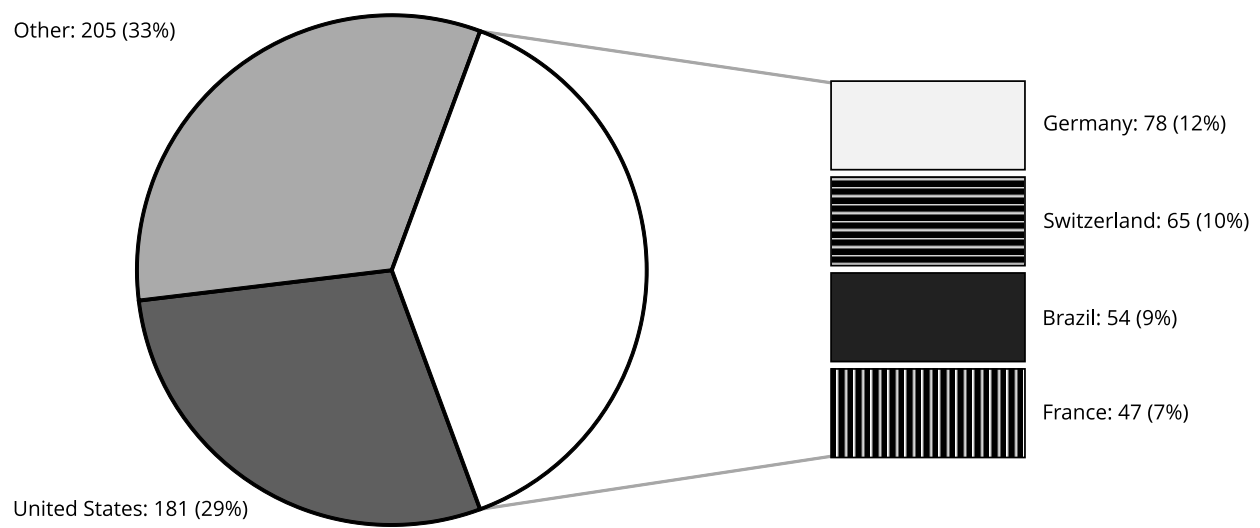

Source: prepared by the authors, based on the special tabulation by the Economic Affairs Advisory (Aecon/INPI). 


\section{Figure 2}

Deposit and grant of the pharmaceutical patents per year.

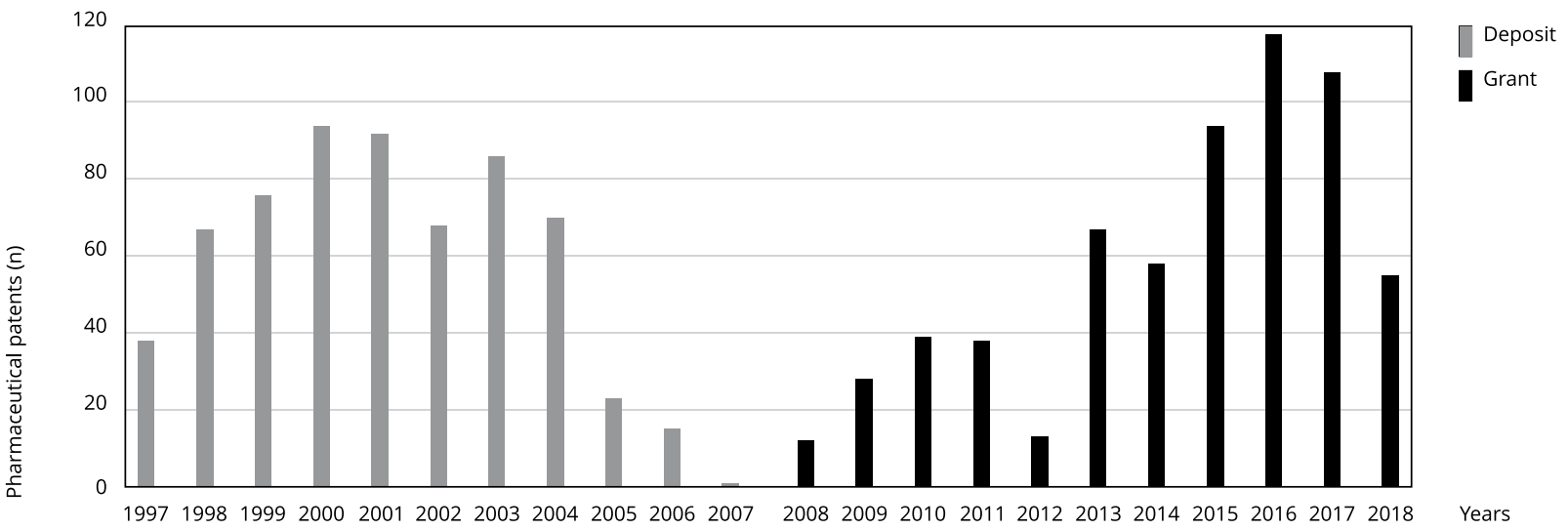

Source: prepared by the authors, based on the special tabulation by the Economic Affairs Advisory of the Brazilian National Institute of Industrial Property (Aecon/INPI). 
for prior consent. While one was sent back due to not being included in Art. 229-C requirements, Anvisa had to consent to the other nine (81.8\%) fast-tracked pharmaceutical applications.

\section{Prosecution periods}

The prosecution of the 630 patents here analyzed lasted from deposit to grant. In this time frame, four periods can be estimated: (a) from the deposit to the publication; (b) from the deposit to the first technical statement; (c) from the first technical statement to the grant; and (d) from the forwarding to Anvisa for prior consent to its return. Period (d) is necessarily contained in period (c), since forwarding to Anvisa is considered one of the first possible technical statements. The first technical statement was considered the first Office action that fell into one of the categories: (a) the first technical requirement; (b) the first technical opinion; (c) forwarding to Anvisa for prior consent; (d) the deferment decision; or (e) the rejection decision 18. Forwarding to Anvisa was considered a first technical statement because $81.3 \%$ of consented applications were examined first by Anvisa and later by the INPI. Therefore, ignoring this as the first technical statement would mean to overlook part of the actual examination.

Finally, these periods allow the estimation of a temporal proxy of the pharmaceutical patent backlog: subtracting all the three years that the applicant has to must request the substantive examination from the period between the deposit and the first technical statement. This period represents how long the application could already be under examination but remains idle in the backlog pile, as seen in Figure 3.

The most general result is that the INPI took, on average, 13.5 years to grant these 630 pharmaceutical patents, hence, an average extension of three and a half years. If averages are estimated only for the patents granted in a given year, the lag continuously grows from 10.7 years in 2008 to 14.7 in 2017. This means that the examination is getting progressively more lagged, representing the incapacity of the office to deal with the influx of new applications given the size of the backlog. Furthermore, it is alarming that one application was granted after 19.6 years of prosecution, which means it will have protection for 29.6 years. Nonetheless, the average for 2018 was at 14.1 years, considering grants issued until May 14th, so the INPI might finally be able to reverse this trend - albeit still extending the term considerably.

These results are in line with the INPI's own estimations for 2017: 12.8 years to issue a final decision on pharmaceutical applications 19 . The difference is that in this study only the decisions of grant

\section{Figure 3}

Brazilian pharmaceutical patent prosecution timeline.

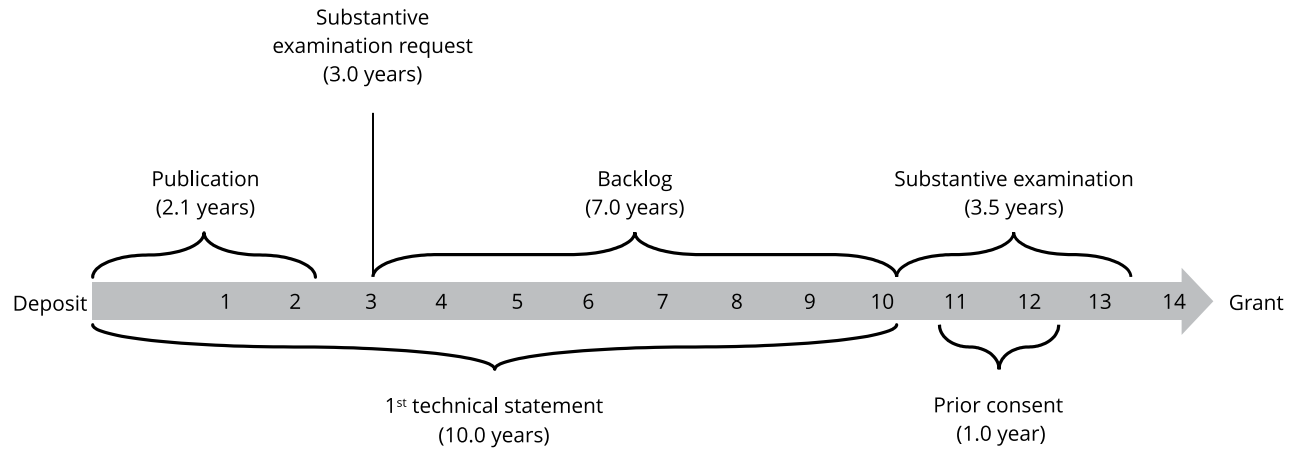

Source: prepared by the authors, based on the special tabulation by the Economic Affairs Advisory of the Brazilian National Institute of Industrial Property (Aecon/INPI). 
with extension were considered ( $92.2 \%$ of total grants), whereas the INPI data also considered grants without extension, rejections, and technical dismissals, not being suited for precise estimations of average extension.

Another important result is that the first technical statement is presented, on average, after ten years of prosecution, which means that considering that the applicant requested the substantive examination on the last day, the application remained idle on the backlog pile for seven years - double the time it takes to examine them. This estimation is perhaps the major finding of this study because it means understanding the backlog not only as a quantity of pending applications but also as idle time in the examination, which herein is called a temporal backlog.

Since the overall average prosecution time is 13.5 years and the first technical statement comes after 10 years from the deposit, we can conclude that the examiner takes only three and a half years, on average, to grant the patent after the first technical statement. Moreover, when Anvisa had a role, it took one year and one month to decide on prior consent, on average, and the INPI examiner was only responsible for two years and 10 months. This is another important contribution of this paper because it shows that the average length of substantive examination when Anvisa is involved is three years and 10 months, whereas, without Anvisa, the average is two years and seven months. Therefore, prior consent only adds 15 months to the average prosecution period. Since the 2017 Joint Ordinance reduced Anvisa's role, it should be even faster. Furthermore, it should be noted that only 434 (68.9\%) applications were sent to Anvisa.

To check the robustness of these findings, it was also estimated that, considering every pharmaceutical grant that the INPI had issued until the data was extracted, $97.7 \%$ of the patents that required Anvisa's prior consent were extended, whereas $88.5 \%$ of the patents that were granted without the need for consent were extended. This shows that including Anvisa in the prosecution only raised the likelihood of extension by $9.2 \%$. The two percentages combined reach $92.2 \%$ average extension for all pharmaceutical grants. Therefore, Anvisa only marginally contributes to the extension of patent terms by delaying prosecution, rejecting any hypothesis that prior consent is the sole or biggest reason for extensions.

In addition, in the few fast-tracked applications, the average examination was even faster, with an average of three years. Therefore, the substantive examination of pharmaceutical patents is fast, but it takes long to begin. The delay of the substantive examination is, thus, not the examiner's fault, but due to the temporal backlog. It is crucial to understand this relationship between the duration of the exam and the backlog.

In conclusion, more than half of the 13.5 years of prosecution, from deposit to grant, is the temporal backlog in which the application is waiting for the examination to begin, with the first technical statement. Surprisingly, the halt in the prosecution lasts for twice the substantive examination period. This is a direct effect of the chronic shortage of patent examiners at the INPI given the backlog of the pending applications.

\section{Discussion}

This paper proved that the rule for the pharmaceutical patent term in Brazil is to follow the Sole Paragraph and not the head provision of the Art. 40 of the LPI. This means that, in 630 of the $683(92.2 \%)$ cases in which extension was possible, the patents will have a longer protection time than the TRIPS Agreement demanded. This private gain for the patentee is not joined by an effective benefit for society, because there is no greater dissemination of knowledge or introduction of more innovative products. Moreover, this policy instrument has significant negative effects on public health issues that probably outweigh the benefits of patent protection, especially in a country with a Brazilian Unified National Health System (SUS) that covers over 210 million people under the egalitarian principle that health is a right and should be accessible to all (Art. 196 of the 1988 Constitution). In the extended protection periods, the individuals and the government will be prohibited from buying generic versions of the protected drug produced nationally or even internationally (Art. 42 of the LPI). One study found that delaying the introduction of generics can increase the costs to SUS of buying just nine drugs in up to BRL 3.9 billion 20. 
It is necessary to recognize that removing the minimum term provision without reducing the prosecution time is also an unbalanced situation because it represents damages to the patentees. The first damage is the higher percentage of the term of a patent in which the patentee only has provisional rights and not de facto rights. The provisional rights, as defined by the Art. 44 of the LPI, are guarantees that if the patent is granted, the applicant will be able to demand retroactive compensation if any violation happened while the application was still under prosecution. If nothing changes in the trend of longer prosecutions, another damage to patentees would be the possibility of some never having the de facto right to act exclusively in the commercial exploitation of their invention, since the patents may be granted after 20 years from the deposit date, no longer having protection. This may weaken the private reward, given it would increase legal uncertainty over pharmaceutical patents, which could stimulate patent right infringement. Therefore, the social benefit of extension would be to avoid a disincentive to the invention and ultimately to innovation. In this line of argument, there would be a balanced rationale in minimum terms.

This potential benefit argument is compromised by the fact that the provisional rights guaranteed by Art. 44 deter competitors from copying the invention even when the grant is not certain - which may not happen in the end, meaning the applicant will have possibly enjoyed exclusivity even if the invention was not patentable. Besides, the Brazilian pharmaceutical market, which is the ninth biggest in the world in 2019 21, is too attractive to be dismissed. Furthermore, the R\&D pipeline of the pharmaceutical industry correlates to most of the prosecution time even in these delayed cases, which means that, even if the patent was granted, there would be no immediate product release 12,13,14. Therefore, even if there was a disincentive to the patentees, it probably would not be meaningful, or at least much inferior to the negative impact on public health challenges.

The INPI administration is the key variable to understanding and solving this equation. There is a unanimous criticism of the fact that the INPI does not have financial autonomy, even though determined in Act n. 5,648 17, which created the office, and in the LPI. The INPI is a federal authority that has had more revenue than expenditure in the past years, meanwhile, it cannot hire enough staff or provide them with the necessary infrastructure. To which interests an inefficient INPI attends is not the theme of this study but should be investigated.

One recommendation that emerges organically from the results of this paper is to focus not on legislative proposals, but administrative strengthening. The risk of trying to approve one desirable and approving several other undesirable projects is high. This would be detrimental to the efforts to prevent Brazil from introducing other TRIPS-plus elements to the LPI that could extend the scope, strength, and term of patents. In parallel, there is also a declaration of unconstitutionality to be judged by the Brazilian Supreme Court that could eliminate the extension clause in the Direct Unconstitutionality Action n. 5,52922.

This paper shows that the best way to repeal the minimum term is to nullify its effect by administrative reform. If the INPI can improve the speed of the patent exam, there will be no need for the Sole Paragraph, and it will be easier to remove it from the LPI. There are several strategies that the INPI can adopt to accelerate the examination and many of them are already being adopted and have been increasing productivity. One strategy that deserves special attention involves the fast-tracking programs, which are not as effective as expected. The main concern with fast-tracking is that it could, eventually, just change the backlog of regular applications for a backlog of fast-tracked applications. Furthermore, applicants should be discouraged from applying to these programs if there is a minimum term clause. If the INPI is expected to extend the term, the applicant's interest in the longest exam increases, aiming at maximizing the period of exclusivity. Therefore, the minimum term clause has negative externalities for other strategies that the office could use to reduce the backlog and streamline prosecution.

Two other actions from the INPI to tackle the backlog are best analyzed with recent data. The backlog in January 2019 consisted of 207.270 patent applications pending final decision and the number of examiners was 32323,24 . This represented an impressive reduction of the backlog per examiner per year, from 1,093 to 642. The reduction of the ratio was much more driven by the increase in the number of examiners (56.8\%) than the shrinking of the backlog itself (8.0\%). Since then, the INPI has taken two actions that make backlog analyses more complicated, one methodological and another administrative. In March 2019, it changed the method for estimation of backlog that now only 
includes applications that have already requested substantive examination. This caused an automatic reduction of the backlog in roughly a fourth that by no means represents a better or faster prosecution.

Furthermore, the INPI launched the Backlog Combat Plan in September 2019, with Resolutions n. 240 and n. 241. The Plan aimed at applications that: (a) have not received any technical statement; (b) are not in any fast-tracking program; (c) have not received any subsidy from other parties, including Anvisa, that opposed the grant; and (d) were filed before 2017. If the same application had already received a prior search report from any other patent office, the applicant would be requested to adjust the Brazilian application. If there was no report done from another office, the INPI would do it. If the applicant failed to reply to these actions, the application would be considered abandoned.

Actually, the Plan has two basic effects. On the one hand, it promotes the abandonment of many applications, which is proven by the fact that the INPI considered abandoned (arquivamentos, in Portuguese) 54.6\% more applications from January to September in 2020 than in these months in 2019. On the other hand, the Plan promotes that more applications be granted since the INPI will accept any prior search report that supports the application as novel, which is reflected by the increased number of grants (23.6\%) and reduced number of rejections (18.3\%), comparing the same periods 25 .

After these measures, the total backlog in May 2020 was 141,659, under the INPI's new methodology, or 187,243, under the previous 26 . Also, there were 307 examiners in May, which brings the backlog per examiner down to 461, or 610. It is important to recognize the improvement in the INPI's situation from 1,093 in 2017. However, the reduction is far less impressive when looking at the ratio of 642 in 2019. This is an indicator that the effective way to reduce the backlog per examiner is through hiring an adequate number of examiners. Nonetheless, the INPI is still far from this adequate level since, even in the new methodology, the ratio far surpasses the average of 112 pending applications per examiner for the IP5 offices.

For pharmaceuticals and biopharmaceuticals, the latest information presented by the INPI under the previous backlog methodology was 22,885, with 40 dedicated examiners (ratio of 572 per examiner) in April 2017 27. Combining the hiring of more examiners, the reduction of Anvisa's prior consent, the methodological change, and the Plan, one could expect a great improvement in the efficiency of prosecution of pharmaceutical applications. In the first semester of 2020, the INPI has already made twice the number of decisions than in 2017, which could suggest that the office has grown in productivity four times. However, there were 20,820 pending applications under the new methodology - which suggests that the total backlog is even bigger. Furthermore, the average prosecution time is still over 10 years, with $51.2 \%$ of the grants in 2020 falling under the term extension clause 19 .

This data further confirms the findings of the study by showing that the central issue to be solved is as easy to perceive as apparently difficult to implement: the INPI does not have enough examiners to deal with the volume of applications that Brazil receives. Even though examiners seem to have considerably high productivity, the office itself is inefficient due to the administrative flaw of not being able to respond to the demand for examination. Either Brazil, as a society and State, recognizes the need to constitute sufficient and qualified staff and infrastructure, giving INPI the capability to perform its functions efficiently, or it will be left with a perpetual backlog that delays prosecution and causes term extension.

\section{Conclusion}

This study addressed a controversial subject with a novel methodology. It investigated the effect of the prosecution of patent applications in Brazil on the forceful introduction of pharmaceutical patenting after TRIPS. Even if the TRIPS Agreement's requirements are considered a balanced contract, Brazil went further and created more restrictive exceptions, which became the rule, leaning the policy towards the private rewards of this system. The main conclusion of this study is that the LPI, and how it is implemented by the INPI, created a system that favors the patentee to the detriment of society and competition, producing imbalanced stimuli, which hamper the innovation goals of patenting.

It is important to emphasize that this biased implementation represents both the strengthening of anticompetitive effects, which generate extraordinary gains for the patentee without direct and balanced compensation for society, and the greater difficulty to operate legal remedies to anticom- 
petitive effects of patenting. However, this paper does not go further into analyzing the market and public health effects. Furthermore, the data was restricted to granted patents, hence missing the information on rejected or abandoned applications. Therefore, the limitations of this study should inspire future studies.

Nonetheless, a particular aspect of the patent backlog that had been hidden was brought to light. The backlog cannot be seen just as a volume of pending patent applications, or even pending applications per examiner. There is a temporal dimension of extreme relevance. Pharmaceutical patent applications prosecuted by the LPI have remained idle for an average of seven years while they waited for the first technical statement. This period is double the length of the substantive examination. Therefore, extension is not caused by the examiner since the substantive examination itself is reasonably fast. In addition, there is a limit to how fast the examination could be without compromising quality.

Therefore, the main political implication of this study is the recognition that the INPI's examiners have considerably high productivity, but the office has been rendered inefficient by poor administrative conditions, and this is what caused the extension of $92.2 \%$ of pharmaceutical patents. Considering the risk of reforming the LPI and creating an even more unbalanced version, and the inability to end the backlog without increasing the number of examiners, the INPI must be strengthened as the technical body for intellectual property examination and protection, with effective autonomy to use its funds to hire more examiners and invest in infrastructure. This is the only solution that effectively tackles the nature of the problem and promotes balance in Brazilian pharmaceutical patenting.

\section{Contributors}

E. Mercadante participated in the project design, data analysis and interpretation, writing, critical review of the intellectual content, and final approval for publication of the paper. J. Paranhos participated in the project design, data analysis and interpretation, writing, and critical review of the intellectual content of the paper.

\section{Additional informations}

ORCID: Eduardo Mercadante (0000-0001-55974863); Julia Paranhos (0000-0003-4425-7484).

\section{Acknowledgments}

The authors thank Prof. Ken Shadlen (London School of Economics) for the attentive remarks. Likewise, the Economic Affairs Advisory of the Brazilian National Institute of Industrial Property (Aecon/INPI) for the Special Tabulation. This work was supported by the Brazilian Graduate Studies Coordinating Board (CAPES), which funded E. Mercadante's Master's degree in Public Policies, Strategies, and Development at the Federal University of Rio de Janeiro (PPED/UFRJ).

\section{References}

1. World Trade Organization. Agreement on trade-related aspects of intellectual property rights. https://www.wto.org/english/ tratop_e/trips_e/trips_e.htm (accessed on 02/ Nov/2020).

2. Bermudez J, Epsztejn R, Oliveira M, Hasenclever L. O Acordo TRIPS da OMC e a proteção patentária no Brasil: mudanças recentes e implicações para a produção local e o acesso aos medicamentos. Rio de Janeiro: Escola Nacional de Saúde Pública, Fundação Oswaldo Cruz; 2000.

3. Correa C. Intellectual property rights, the WTO and developing countries: the TRIPS agreement and policy options. London: Zed; 2000.

4. Drahos P. The global governance of knowledge: patent offices and their clients. Cambridge: Cambridge University Press; 2010.

5. Shadlen K. Coalitions and compliance: the political economy of pharmaceutical patents in Latin America. Oxford: Oxford University Press; 2017.

6. Brasil. Lei no 9.279, de 14 de maio de 1996. Regula direitos e obrigações relativos à propriedade industrial. Diário Oficial da União 1996; 15 mai. 
7. Chaves GC, Oliveira MA, Hasenclever L, Melo LM. A evolução do sistema internacional de propriedade intelectual: proteção patentária para o setor farmacêutico e acesso a medicamentos. Cad Saúde Pública 2007; 23:257-67.

8. Sampat B, Shadlen K. Secondary pharmaceutical patenting: a global perspective. Res Policy 2017; 46:693-707.

9. Granstrand O. Innovation and intellectual property rights. In: Fagerberg J, Mowery D, Nelson R, editors. The Oxford handbook of innovation. Oxford: Oxford University Press; 2005. p. 266-90.

10. Andersen B. If 'intellectual property rights' is the answer, what is the question? Revising the patent controversies. In: Andersen B, editor. Intellectual property rights: innovation, governance and the institutional environment. Cheltenham: Edward Elgar Publishing; 2006. p. 109-47.

11. Pavitt K. Sectoral patterns of technical change: towards a taxonomy and a theory. Res Policy 1984; 13:343-73.

12. Achilladelis B, Antonakis N. The dynamics of technological innovation: the case of the pharmaceutical industry. Res Policy 2001; 30:535-88.

13. Hasenclever L, Fialho B, Klein H, Zaire C. Economia industrial de empresas farmacêuticas. Rio de Janeiro: E-papers Serviços Editoriais; 2010.

14. Scherer F. Pharmaceutical innovation. In: Hall B, Rosenberg N. editors. Handbook of the economics of innovation. v. 1. Amsterdam: North Holland; 2010. p. 539-74.

15. World Intellectual Property Organization. IPC and technology correspondence table. https://www.wipo.int/meetings/en/doc_de tails.jsp?doc_id=117672 (accessed on 02/ Nov/2020)

16. Diretoria de Patentes, Instituto Nacional da Propriedade Industrial. Manual para o depositante. Rio de Janeiro: Instituto Nacional da Propriedade Industrial; 2015.

17. Brasil. Lei no 5.648, de 11 de dezembro de 1970. Cria o Instituto Nacional da Propriedade Industrial e dá outras providências. Diário Oficial da União 1970; 14 dec.

18. Diretoria de Patentes, Instituto Nacional da Propriedade Industrial. Criação de uma máquina de estados para os processos de patentes do INPI: relatório executivo. Rio de Janeiro: Instituto Nacional da Propriedade Industrial; 2017.
19. Diretoria de Patentes, Instituto Nacional da Propriedade Industrial. Patentes da área farmacêutica: trâmite administrativo. https:// www.gov.br/inpi/pt-br/servicos/patentes/re latorios-gerenciais-2/BacklogAreaFarmaceu tica16062020.pdf (accessed on 02/Nov/2020).

20. Paranhos J, Mercadante E, Hasenclever L. O custo da extensão da vigência de patentes de medicamentos para o Sistema Único de Saúde. Cad Saúde Pública 2020; 36:e00169719.

21. IQVIA Holdings. Top 10 Pharmaceutical markets worldwide. https://www.iqvia.com/-/ media/iqvia/pdfs/canada/2019-trends/top 10worldwidesales_en_19.pdf (accessed on 02/ Nov/2020).

22. Senado Federal. Acórdão da Ação Direta de Inconstitucionalidade no 5.529 , de 12 de maio de 2021. Diário Oficial da União 2021; 14 mai.

23. Instituto Nacional da Propriedade Industrial. Relatório estoque de pedidos pendentes: janeiro 2019. Brasília: Instituto Nacional da Propriedade Industrial; 2019.

24. Instituto Nacional da Propriedade Industrial. Número de examinadores: 2019. https:// www.gov.br/inpi/pt-br/central-de-conteu do/estatisticas/arquivos/outras-estatisticas-de-propriedade-industrial/ptn_examina dores_2019_12_dirpa.xlsx (accessed on 02/ Nov/2020).

25. Assessoria de Assuntos Econômicos, Instituto Nacional da Propriedade Industrial. Boletim mensal de propriedade industrial: estatísticas preliminares. Rio de Janeiro: Instituto Nacional da Propriedade Industrial; 2020.

26. Assessoria de Assuntos Econômicos, Diretoria Executiva, Instituto Nacional da Propriedade Industrial. Relatório estoque de pedidos pendentes: maio 2020. https://www.gov.br/inpi/ pt-br/acesso-a-informacao/pasta-x/estatisti cas-preliminares/arquivos/documentos/rela torio-estoque-pedidos-pendentes_06-2020. pdf (accessed on 02/Nov/2020).

27. Diretoria de Patentes, Instituto Nacional da Propriedade Industrial. Levantamento das Necessidades de Pessoal na DIRPA: relatório final. https://www.gov.br/inpi/pt-br/aces so-a-informacao/dados-abertos/arquivos/ documentos/relatorio-gerencial-de-patentes/ rgp-mai-2017-ln-pessoal-dirpa.txt (accessed on $02 /$ Nov/2020). 


\section{Resumo}

No Brasil, quando a tramitação de uma patente demora mais de 10 anos, esse tempo adicional é acrescentado à vigência regular de 20 anos. Este artigo analisa todas as patentes farmacêuticas concedidas pelo Instituto Nacional de Propriedade Industrial (INPI) com prorrogação de prazo, e em seguida discute algumas implicações para politicas de propriedade intelectual e de saúde. Em média, os pedidos de patente farmacêuticas esperam sete anos entre o requerimento do exame e o início da análise, que leva apenas três anos e meio. Além do mais, o papel da Agência Nacional de Vigilância Sanitária (Anvisa) na anuência prévia tem efeito marginal sobre o período de tramitação. Portanto, a extensão da vigência das patentes farmacêuticas é provocada pelo alto número de pedidos pendentes por examinador, o que atrasa em até duas vezes o tempo que leva para examinar os pedidos. Logo, soluções adequadas devem focar na redução do acúmulo de pedidos pendentes por examinador no INPI, que causou a extensão de 92\% das patentes farmacêuticas em três anos, em média. Concluise que a politica brasileira para patentes farmacêuticas apresenta um viés em favor do titular da patente. Esse desequilíbrio só será sanado efetivamente quando o INPI tiver autonomia financeira e administrativa para reduzir a razão entre $o$ backlog de pedidos de patentes farmacêuticas e o número de examinadores.

Patentes de Medicamentos; Patentes; Indicadores de Patentes

\section{Resumen}

En Brasil, si la tramitación de una patente tarda más de 10 años, este período extra se añade a la vigencia regular de 20 años. Este trabajo analiza todas las patentes farmacéuticas otorgadas por la Oficina de Patentes Brasileña (INPI) con extensión de su vigencia, $y$ discute posteriormente algumas implicaciones para las politicas de propriedade intelectual y de salud. En promedio, las solicitudes de patentes farmacéuticas esperan siete años desde el requerimiento del examen antes de ser examinadas, lo que tarda solamente tres años $y$ medio. Asimismo, el rol de la Agencia Nacional de Vigilancia Sanitaria (Anvisa) al dar su consentimiento previo tiene un efecto marginal para prolongar la tramitación. Por ello, la extensión de la vigencia de las patentes farmacéuticas está provocada por el número de solicitudes pendientes por examinador, lo que paraliza la tramitación por el doble de período de tiempo que cuesta examinar las solicitudes. Así pues, las soluciones apropiadas deberían centrarse en reducir el acúmulo de solicitudes pendientes por examinador en el INPI, que ha provocado la extensión de la patente en un 92\% de las solicitudes farmacéuticas en tres años y meio, en promedio. Se concluye que la politica de patentes farmacéuticas brasileña está sesgada hacia el titular de la patente. Este desequilibrio solo se corregirá efectivamente cuando el INPI tenga autonomía financeira y administrativa para reducir la razón entre el backlog de solicitudes de patentes farmacéuticas y el número de examinadores.

Patentes de Medicamentos; Patentes; Indicadores de Patentes
Submitted on $19 / \mathrm{Feb} / 2021$

Final version resubmitted on 05/Jun/2021

Approved on 15/Jun/2021 